\title{
パイプ流存在下での斜面の安定性に関する 数値実験
}

\section{NUMERICAL EXPERIMENTS TO ASSESS THE INFLUENCE OF PIPEFLOW ON SLOPE STABILITY}

\author{
堤大三 ${ }^{1} \cdot$ Roy C. Sidle $^{2} \cdot$ 藤田正治 $^{3} \cdot$ 水山高久 $^{4}$ \\ Daizo TSUTSUMI, Roy C. SIDLE, Masaharu FUJITA and Takahisa Mizuyama \\ ${ }^{1}$ 農博 京都大学助手 防災研究所水災害研究部門（广611-0011 宇治市五ヶ庄） \\ ${ }^{2} \mathrm{PhD}$ 京都大学教授 防災研究所地盤災害研究部門（广611-0011 宇治市五ヶ庄） \\ ${ }^{3}$ 正会員 工博 京都大学助教授 防災研究所水災害研究部門（６11-0011 宇治市五ヶ生） \\ ${ }^{4}$ 正会員 農博 京都大学教授 農学研究科森林科学専攻（广606-8502 京都市左京区北白川追分町）
}

\begin{abstract}
Pipeflow is recognized as an important hydrologic control as well as a landslide initiation factor, and the development of a theoretical method to analyze pipeflow process is needed. However, there are few modeling studies of pipeflow, and a general simulation technique for water dynamics in the hillslope scale with soil pipes has not yet been developed. In this study, a general model that describes lateral pipeflow in a hillslope was developed. In the model, matrix flow and pipeflow were calculated by their respective governing equations (Richards' equation and Manning's equation), considering the interaction between these two flow systems. Numerical experiments were conducted to analyze the effect of pipeflow on slope stability. Results indicated that pipe clogging decreases the factor of safety and could be a factor that triggers landslides, and that pipeflow affects the initiation of debris flow after landslides.
\end{abstract}

Key Words: pipeflow, slope stability, Richards'equation, Manning's equation, pipe clogging, debris flow

\section{1.はじめに}

これまでの水文学的観測から，均質な土層を仮定した 従来の浸透流理論では山地斜面における雨水流出機構を 説明できず，土層内には選択的な水の流れが存在するこ とが示唆されてきた. 近年，より詳細な観測により，数 多くの山地斜面においてパイプ (soil pipe) と呼ばれる斜 面にほぼ平行な大孔隙の存在が確認され, 山地斜面の雨 水流出機構に重大な影響を及ぼすことが明らかにされて いる ${ }^{1,2)}$. また, 崩壊発生直後の崩壊地の多くにパイプが 存在し，水の流出が観察されることなどから，パイプに よる選択流が崩壊発生に関与していることが指摘されて いる ${ }^{3)}$. さらに, 「降雨時に発生するパイプの閉塞によっ てパイプ及びその周辺の間隙水圧が上昇することが，崩 壊発生の引金になる.」との仮説も提案されている224.

上記の仮説を含め, どのようなメカニズムでパイプ流 が斜面崩壊に関与するかを検証するためには，従来の浸 透流計算に加え, パイプ存在下での選択流 (パイプ流) を考慮した計算手法の開発が必要である. これまでのと ころ, パイプ流についていくつかの計算手法が提案され ているが，それらは，パイプ内の水圧を一定と仮定した モデル 5)や，観測した流域にのみ適用可能な経験則的なモ
デルの，またはパイプを透水係数の大きな土壤と仮定する モデルクなど, 実際の現象と異なる仮定や, 観測に基づく 経験則を必要とするものであり，その適用には限界があ る. パイプ流と斜面安定の関係を理論的に考察した数少 ない研究のひとつとして，内田・水山 ${ }^{8)}$ は， Jones and Connellyののモデルに類似した計算によってパイプの閉塞 が斜面の安全率の変化に及ぼす影響を検討し，上記の仮 説 2)4)を支持する結果を示した. しかし，パイプ流の計算 は多くの仮定を含んでおり，パイプー周辺土壌間の水移 動やパイプ内の水圧分布等の扱いには，課題が残されて いる.

本研究では，パイプー周辺土壌間の水移動を適切に評 価し，パイプ内の水圧分布の変化を計算することで，害 際の現象を反映したモデル化を行い，パイプ流に関する より汎用的な計算手法を構筑した。 この手法を用い，パ イプを含む仮想的な斜面に対する降雨浸透と流出過程の 数值実験を行うことで, パイプ流が斜面土層の間隙水圧 分布の変化とそれに伴う斜面安全率の変化に及ぼす影響 について検討し，パイプ流が崩壊発生に関与するメカニ ズムについて考察した，さらに，崩壊前後の土砂流動化 を念頭に置き，崩壊後の斜面からの流出量変化について も検討を行った. 


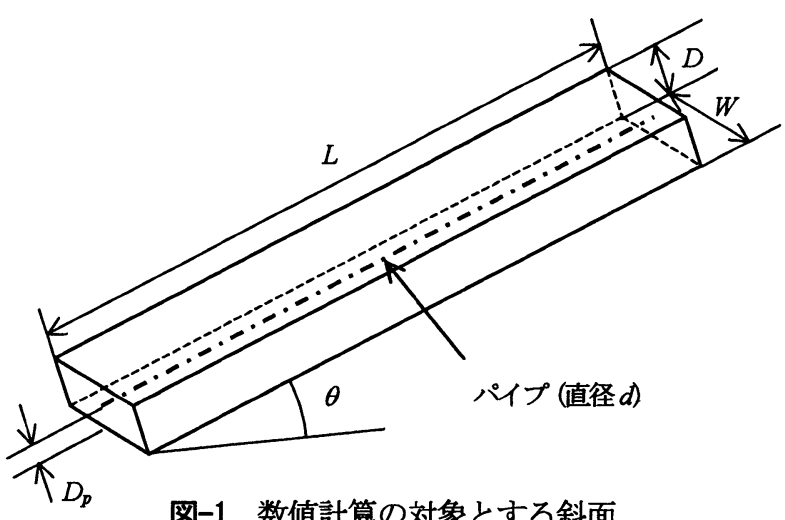

図-1 数值計算の対象とする斜面

\section{2. 数値計算の方法}

\section{（1）パイプ流を考慮した浸透流計算}

斜面は, 最も単純な直方体を仮定し, 傾斜角 $\theta\left(=30^{\circ}\right)$, 斜面長 $L=50 \mathrm{~m}$, 土層厚 $D=1.0 \mathrm{~m}$, 斜面幅 $W=5.0 \mathrm{~m}$ とし た. 土層底面から $D_{p}(=0.2 \mathrm{~m})$ の位置に直径 $d(=2.5,5.0$, $10.0 \mathrm{~cm})$, 長さ $L_{p}$ の円柱形状をしたパイプが, 斜面上端 から下端まで $\left(L_{p}=L\right)$ 連続して存在するものとした (図 $-1)$.

土層内の浸透流は, 式(1)に示寸 Richards 式を有限要素 法により計算し求めた. 有限要素の分割においてパイプ の中心に節点を配置し，パイプを各節点によって分割さ れた「体積を持たない線分」とみなした.

$$
C(\psi) \frac{\partial \psi}{\partial t}=\nabla\{K(\psi)[\nabla(\psi+z)]\}
$$

ここで, $t$ は時間， $C(\psi)$ は土㙵の比水分容量， $K(\psi)$ は透水 係数， $\psi$ は圧力水頭， $z$ は鉛直上向きの座標を表す，パイ プ上の節点が不飽和 $(\psi<0)$ の場合，その部位のパイプ流は 無いものとみなす. 逆に，パイプ上の節点が飽和 $(\psi \geq 0)$ の場合，以下に示子 2 通り（開水路流・管路流）にパイ プ流を分類し（図-2），パイプー周辺土壌間の水移動を考 慮し，土壌浸透流およびパイプ流を計算した。

\section{a) 開水路流}

節点 $i$ での圧力水頭值を $\psi_{i}=0$ とし (Dirichlet 境界)，パ イプに流入（またはパイプから流出）する水量 $S_{i}$ を浸透 流計算において求めた。 節点 $i-1$ から $i$ 間のパイプ流量 $Q_{i-1}$ と $S_{i}$ は, 節点 $i$ から $i+1$ 間のパイプ流量 $Q_{i}$ と水位の上 昇に消費される事から，

$$
Q_{i}=Q_{i-1}+S_{i}-\frac{\left(A_{i}^{(t)}-A_{i}^{(t-\Delta t)}\right)}{\Delta t} \Delta l
$$

ここで, $A_{i}^{(t)}$ と $A_{i}^{(t-\Delta t)}$ は時刻 $t$ と $t-\Delta t$ における節点 $i$ から $i+1$ 間の流水断面積, $\Delta l$ は節点 $i$ から $i+1$ 間のパイプ長, $\Delta t$ は時間ステップを表す. また， $Q_{i}$ を Manning 式にて表わ すと,

$$
Q_{i}=\frac{1}{n} R^{2 / 3} I^{1 / 2} A_{i}^{(t)}
$$

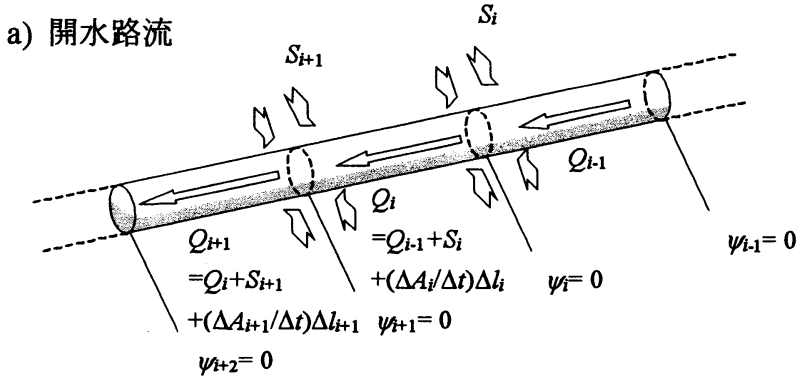

b) 管路流

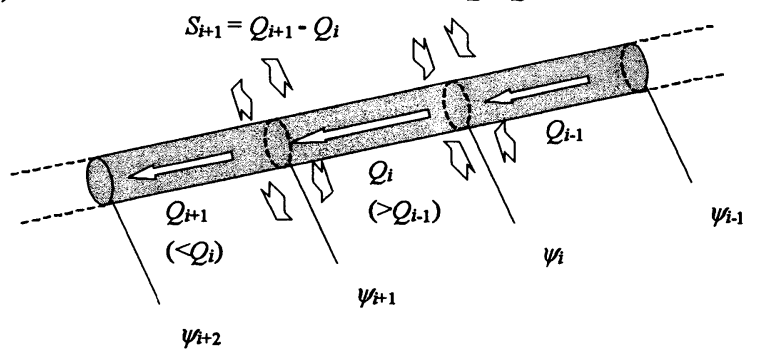

図-2 パイプ流の概念図 : a) 開水路流, b) 管路流 ここで, $n$ は粗度係数， $R$ は径梁，Iはエネルギー勾配 (こ こでは, パイプの勾配 $\sin \theta$ を表す. 式(2)と(3)を連立し, パイプ上流から順に, 収束計算によって $Q_{i}$ と $A_{i}^{(t)}$ を求め た. ただし, $A_{i}^{(i)}<0$ となった場合，節点 $i$ はDirichlet 境界 条件から開放し，パイプ流は無いものとして浸透計算を やり直した. また, $A_{i}^{(t)}>A_{p}$ ( $A_{p}$ はパイプ断面積) となっ た場合も，節点 $i$ は Dirichlet 境界条件から開放し，パイプ 流を管路流に分類して, 浸透計算をやり直した.

\section{b) 管路流}

Manning 式におけるエネルギー勾配を節点間の水理水 頭勾配とし,

$$
I=\frac{\left(\psi_{i}-\psi_{i+1}+\Delta z\right)}{\Delta l}
$$

式(3)，(4)によって流量 $Q_{i}$ を計算した. 各流量の差をパイ プー周辺土壤間における水移動量 $S_{i}$ と考え,

$$
S_{i}=Q_{i}-Q_{i-1}
$$

として節点 $i$ に与え $\left(S_{i}>0\right.$ の場合は吸水項 ; $S_{i}<0$ の場合 は湧水項)，浸透計算を行った. その結果，各節点の圧力 水頭 流量計算を行った.この計算を全節点の $\psi$ が一定值に収束 するまで繰り返した. ただし，計算の過程で $\psi_{i}<0$ となつ た場合は，節点 $i$ をDirichlet 境界条件 $\left(\psi_{i}=0\right)$ とし，開 水路流に分類して，計算をやり直した.

北原の研究 ${ }^{9}$ によると, 実際のパイプ (径 0.96〜3.1cm) を用いた実験において，パイプ流一エネルギー勾配の関 係は Darcy-Weisbach 式に良く適合し，流速を Manning 式 で表現できる事が確認されている．また，その場合の粗 度係数 $n$ は, $0.036 \sim 1.36$ の值を持つ事が示されており, 本研究では粗度係数 $n=0.1$ を一定値として与えた. 

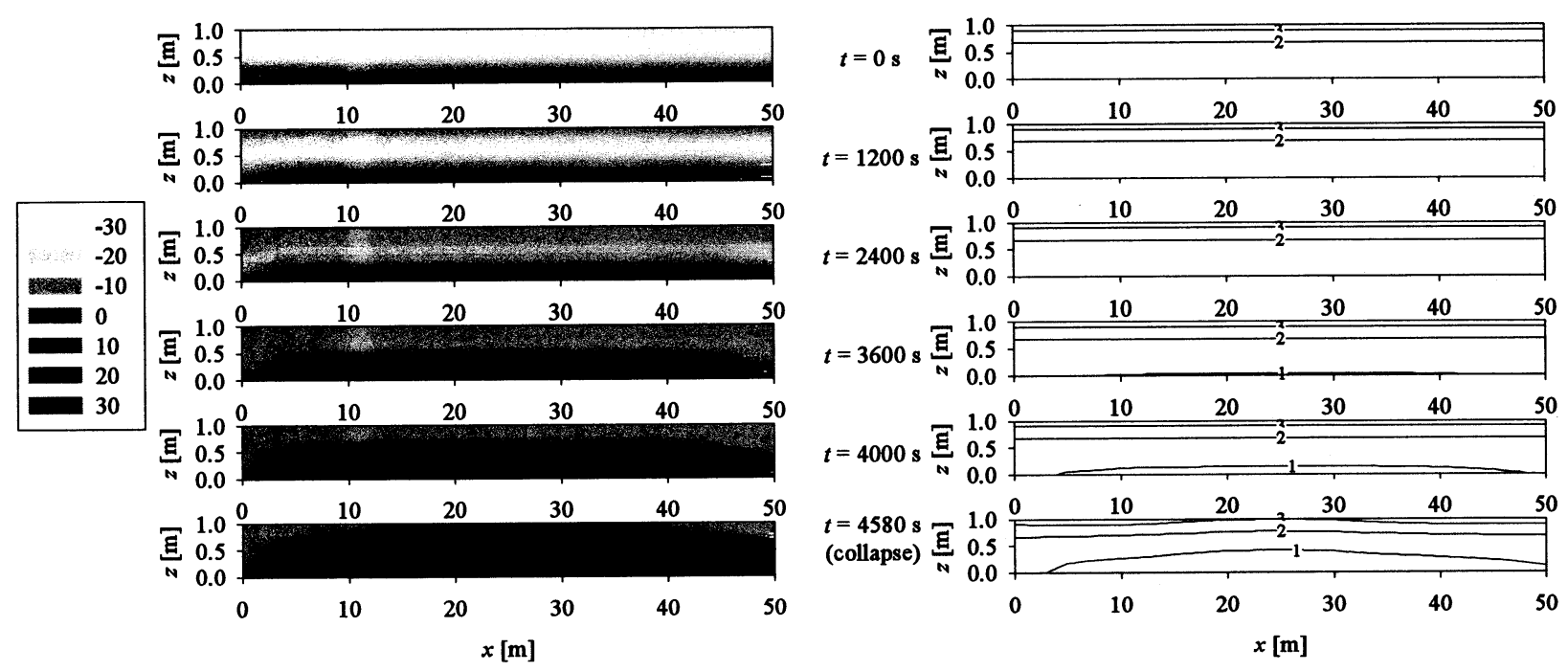

図-3 パイプが無い場合（Casel）の斜面土層内の圧力水頭 $\psi[\mathrm{cm}]$ 分布（左）と安全率 $F($ 右）の変化

なお、ここに示した手法により，既往の室内実験 ${ }^{10)}$ 再現計算することで計算手法の検証を行い，その有効性 を確認している.

\section{(2) 斜面安定計算}

2 次元簡易ビショップ法により，式(6)を用いて斜面安 定率 $F_{s}$ を計算した. すべり面は土層底面と接触する円弧 を仮定，すべり土塊を 10 スライスに分割し，斜面絉断方 向の位置および円弧半径を変化させて, 最小となる安全 率 $F_{s}$ を求めた.

$$
F_{s}=\frac{\sum \frac{c b+(w-u b) \tan \phi}{\left(1+\tan \phi \tan \alpha / F_{s}\right) \cos \alpha}}{\sum w \sin \alpha}
$$

ここで, $c$ は粘着力, $\phi$ は内部摩擦角, $w$ は土塊の自重, $u$ はスライス底面に作用する平均間隙水圧, $d$ は各スライス のすべり面と水平面のなす角, $b$ はスライス幅である. 既 往の研究 ${ }^{8)}$ を参照し, $c=35 \mathrm{gf} / \mathrm{cm}^{2}, \phi=25^{\circ}$, 土塊の比重 は, 飽和の值を想定し $2.0 \mathrm{~g} / \mathrm{cm}^{3}$ 一定值とした. 土塊に作 用する間隙水圧 $u$ は, 浸透流計算において得られた圧力 水頭を斜面横断方向に平均することで求めた. このため, 斜面幅 $W$ が安全率に影響する事になる. 3 次元で計算さ れる間隙水圧分布を用いて 2 次元の斜面安定解析を行う ことには上記の矛盾を伴うが，これまで行われた崩壊跡 地の観察結果のまとめによると ${ }^{8)}$, パイプの存在が確認さ れた崩壊地の崩壊面幅は 5〜20 m であることから，斜面 幅 $W=5 \mathrm{~m}$ は妥当な值であるか安全側に評価していると 言える. また，側面のせん断抵抗力を無視している事か ら，概ね安全側に評価した解析となっている.

\section{（3）数値実験の条件}

浸透計算の初期条件として，土層底面加ら斜面垂直方 向に $0.175 \mathrm{~m}$ に地下水面を与えた. 境界条件としては,
表-1 数值実験の条件

\begin{tabular}{llc}
\hline & パイプ条件 & 閉塞(開放)時刻 [s] \\
\hline Case1 & パイプなし & - \\
Case2 & パイプ閉塞なし & - \\
Case3 & パイプ下流端(0-10m)閉塞 & 0 \\
Case4 & パイプ下流端(0-10m)閉塞 & 3600 \\
Case5 & パイプ中間部(20-30m)閉塞 & 0 \\
Case6 & パイプ中間部(20-30m)閉塞 & 3600 \\
Case7 & パイプ閉塞部(0-10m)開放 & 3600 \\
\hline
\end{tabular}

最も単純な条件を想定し，土層表面には $50 \mathrm{~mm} / \mathrm{hr}$ の降雨 を与え，土層下流端は大気開放条件とし，それ以外の境 界 (土層上流端，底面，側面）は全て no-flux 境界条件と

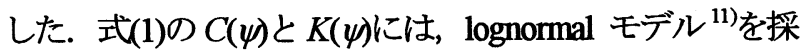
用し, 森林土埪の平均的なパラメーター $\left(K_{s}=0.00537 \mathrm{~cm} / \mathrm{s}\right.$, $\theta_{r}=0.398, \theta_{s}=0.645, \psi_{m}=-43.9 \mathrm{~cm}, \sigma=1.19 ）$ を用いた.

数值実験は，表一 1 に示寸 7 通りの条件で，異なる 3 種類のパイプ直径 $d(2.5,5.0,10.0 \mathrm{~cm})$ についてそれぞれ 行った.

\section{3. 数值実験の結果と考察}

\section{（1）土壤の圧力水頭分布および安全率分布の変化}

降雨中、何らかの原因（水流によるパイプ壁面の侵食 土砂等) でパイプが閉塞し，その部分の間隙水圧が上昇 することで斜面安定性が低下するとの仮説を検証するた め, パイプが無い場合 (Casel) と途中でパイプが閉塞す る場合 (Case4, $d=5.0 \mathrm{~cm}$ ) の圧力水頭分布の斜面横断方

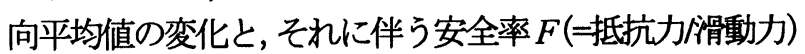
分布変化を図-3，4にそれぞれ示す (ここでの安全率とは 別に，先に示した簡易ビショップ法による安全率 $F_{s}$ も同 時に計算し崩壊の判定を行っている). 斜面は傾斜角 $\theta=$ 30 であるが，図-3，4では水平に表示している. 

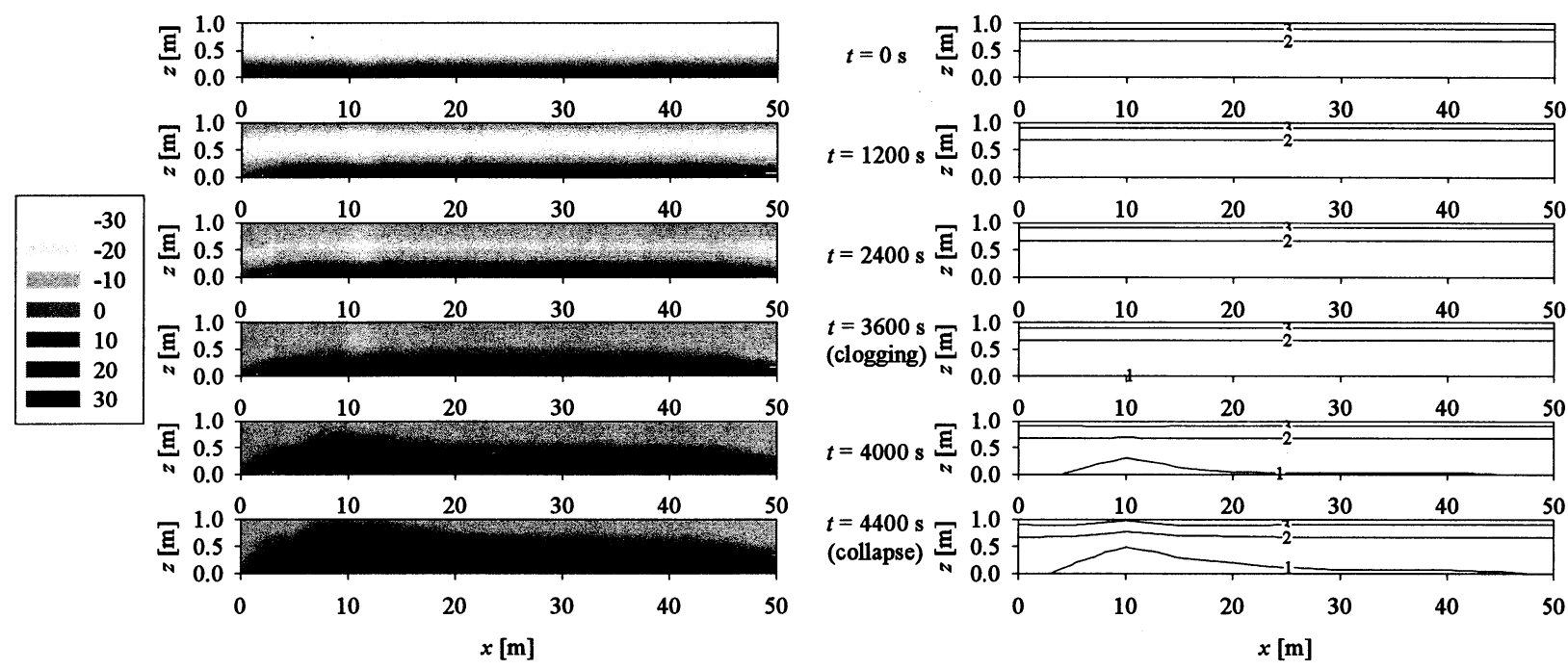

図-4 降雨中のパイプ閉塞（Case4, $d=5.0 \mathrm{~cm} ）$ に伴う斜面士層内の圧力水頭 $\psi[\mathrm{cm}]$ 分布（左）と安全率 $F($ 右）の変化

パイプが無い場合（図-3），土層表面から降雨が徐々に 浸透し，斜面全体が比較的均等に湿潤状態になった. $t=$ $3600 \mathrm{~s}$ 以降，地下水面の上昇が顕著になり，それに伴っ て斜面内の安全率が低下し，最終的に簡易ビショップ法 により計算された安全率が $F_{s}<1.0$ となり, 斜面崩壊が発 生した $(t=4580 \mathrm{~s})$.

パイプが途中で閉塞する場合（図-4）もパイプが無い 場合と同様，初期段階では土層表面から降雨が徐々に浸 透し，斜面全体が比較的均等に湿潤状態になった $(t=0$ 〜3600 s). ただし, 地下水面の上昇は少し遅れており（ $t$ $=3600 \mathrm{~s}$ ), パイプ流による排水機能が働いている事が判 る. パイプの閉塞後 $(t=3600 \mathrm{~s} \sim)$, それまでパイプを流 れていた水が出口を失ったことで, 閉塞部の直上流部の 圧力水頭が急激に上昇し，それに伴って安全率が低下し た. その結果, パイプ閉塞から $800 \mathrm{~s}$ 後に $F_{s}<1.0$ となり, 斜面崩壊が発生した $(t=4400 \mathrm{~s})$. この場合, 圧力水頭の 高い領域（安全率の低い領域）は，パイプが無い場合は 斜面全体に及んでいるのに対し，パイプが途中で閉塞す る場合は，パイプ閉塞部の直上流部に集中している.こ の様に，ある条件のもとで，パイプ流は土層中の水を排 水し地下水面の上昇を抑制するが，パイプの閉塞は急激 な間隙水圧の上昇を引き起こし，斜面崩壊発生の引金と なる事が確認された.

\section{（2）崩壊時刻・位置・規模へのパイプ流の影響}

全ての数值実験について, 崩壊発生の時刻（表-2）を 比較する. ここでは, 崩壊発生時刻が早ければ崩壊発生 までの降水量が少なく，より規模の小さい降雨でも崩壊 するとの観点から，斜面崩壊の危険度が高いと考える. パイプの存在しない斜面（Case1）に対して, パイプが存 在しかつ閉塞しない斜面（Case2）では，崩壊発生時刻が 遅れる傾向が見られた。 特に $d=10.0 \mathrm{~cm}$ の場合, 計算時 間 $7200 \mathrm{~s}$ の間に崩壊は発生せず，パイプの排水機能が土

\begin{tabular}{clll} 
& 表一2 & \multicolumn{2}{c}{ 崩壊 $\left(F_{s}=1.0\right)$ のイミング } \\
\hline \multicolumn{4}{c}{ 崩壊発生時刻 (Case1 上の差) [s] } \\
\hline Case1 & \multicolumn{3}{c}{$4580(-)$} \\
\hline$d[\mathrm{~cm}]$ & \multicolumn{1}{c}{2.5} & 5.0 & 10.0 \\
\hline Case2 & $4640(+60)$ & $5060(+480)$ & 崩壊せず \\
Case3 & $4500(-80)$ & $4180(-400)$ & $4060(-520)$ \\
Case4 & $4580(0)$ & $4400(-180)$ & $4280(-300)$ \\
Case5 & $4540(-40)$ & $4380(-200)$ & $4340(-240)$ \\
Case6 & $4620(+40)$ & $4560(-20)$ & $4540(-40)$ \\
Case7 & $4560(-20)$ & $4800(+220)$ & 崩壊せず \\
\hline
\end{tabular}

層内の間隙水圧を減少させ，斜面を安定化することを示 している. 初めからパイプが閉塞している場合 (Case3, 5) と, 降雨途中で閉塞する場合 (Case4,6) では, 初めから 閉塞している場合の方が崩壊発生時刻は早く, 降雨途中 で閉塞することが重要なのではなく，出口の無いパイプ および不連続なパイプなどの構造自体が斜面を不安定に している要因である事を示している. 数值計算の過程で, パイプが初めから閉塞している場合でも, パイプ径 $d \geq$ $5.0 \mathrm{~cm}$ の多くの部分で, 水はパイプ中を開水路流として 流れ，周りの土層中の浸透流よりも早く下流に輸送され， 閉塞部でパイプから土層へ逆流する事によって圧力水頭 が上昇していることが確認された. パイプの閉塞が下流 端の場合 (Case3,4) と斜面中間部 (Case5,6) の場合とで は，閉塞部より上流が長い (集水域の大きい) 下流部閉 塞の方が，より崩壊時刻が早まり危険である事が示され ている. なお，上記の全ての傾向はパイプ径が大きくな るほど顕著になり, 逆に $d=2.5 \mathrm{~cm}$ の場合は, どの Case においてもパイプが無い場合（Casel）と比較してそれほ ど大きな差は見られない. $d=2.5 \mathrm{~cm}$ の場合，パイプ流は 早い段階で管路流となることが確認されており，排水能 力が小さい事がうかがえる. パイプ径が大きく，排水能 力の高い場合ほど斜面安定化に対する寄与は大きいが, 
表-3 崩壊中心までの斜面下端からの距離と崩壊長

\begin{tabular}{llcc}
\hline & \multicolumn{3}{c}{ 距離 (崩買長) $[\mathrm{m}]$} \\
\hline Case1 & & $22.4(18.2)$ & \\
\hline$d[\mathrm{~cm}]$ & 2.5 & 5.0 & 10.0 \\
\hline Case2 & $19.0(18.2)$ & $14.6(18.2)$ & - \\
Case3 & $12.6(16.5)$ & $10.0(11.0)$ & $10.0(11.0)$ \\
Case4 & $14.0(17.0)$ & $10.0(11.0)$ & $10.0(11.0)$ \\
Case5 & $27.0(17.0)$ & $26.0(11.3)$ & $26.0(11.3)$ \\
Case6 & $25.1(18.2)$ & $26.0(11.3)$ & $26.0(11.3)$ \\
Case7 & $15.3(16.7)$ & $10.3(18.2)$ & - \\
\hline
\end{tabular}

それが閉塞している場合は，逆に斜面を不安定にする危 険性も大きいと言える.

崩壊発生位置（斜面下端から崩壊中心までの距離）お よび崩壊長さ（表-3）について比較すると, パイプが閉 塞している場合 (Case3〜6) 閉塞部の直上流部 (Case3, 4) か, 閉塞部 $(C a s e 5,6)$ での崩壊発生が顕著に見られる. これは，図-4に示した様に，閉塞部の直上流部で間隙水 圧が上昇する事によりその位置での安全率が低下する現 象と良く適合している. パイプ径 $d \geq 5.0 \mathrm{~cm}$ で閉塞がある 場合，崩壊長は短くなる傾向が見られる．パイプが無い 場合 (Casel) およびパイプがあっても閉塞していない場 合 (Case2)，間隙水圧は斜面全体で比較的均等に上昇す るのに対し，閉塞がある場合は図-4に示したように，閉 塞部の近傍で局所的に間隙水圧が上昇するため, より小 さい円弧をすべり面に持つ場合の安全率が最小となるた めと考えられる. ただし，二次的な崩壊や崩土の流動化 などを考えると，パイプ閉塞を原因とする崩壊の規模が 必ず小さくなると断言する事はできない，また，この場 合も $d=2.5 \mathrm{~cm}$ において, 上記の傾向は顕著ではなく, パ イプ流による影響は小さいと言える.

\section{（3）土層浸透流量・パイプ流量の変化}

崩壊土の土石流化を考える時, 斜面崩壊までの過程だ けでなく，崩買後の斜面から崩壊土に供給される水量の 変化について検討する事も重要な課題である. 本研究で は，斜面崩壊後の過程においても，表-3に示した崩壊中 心位置を斜面下流端とし，そこから上流部の斜面を対象 に数值計算を継続し，土層浸透流とパイプ流ならびに表 面流による流出量変化を，崩壊以前から崩壊後の過程ま で連続して求めた. $d=5.0 \mathrm{~cm}$ の場合を例に, Casel, 2,3,7 の結果を示し考察する.

パイプが無い場合（図-5a），崩壊と同時に崩壊面が大 気に開放された事で土層浸透による流出量が急増し，そ の後莪减している．また，崩㯰時には表面流による流出 量が急増しており，地下水面が地表面に到達した事を示 している. 崩壊後の流出量ししては，表面流による寄与 が大きい，パイプの閉塞が無い場合 (図-5b)，土層浸透 による流出量はパイプが無い場合と同程度であるが，そ
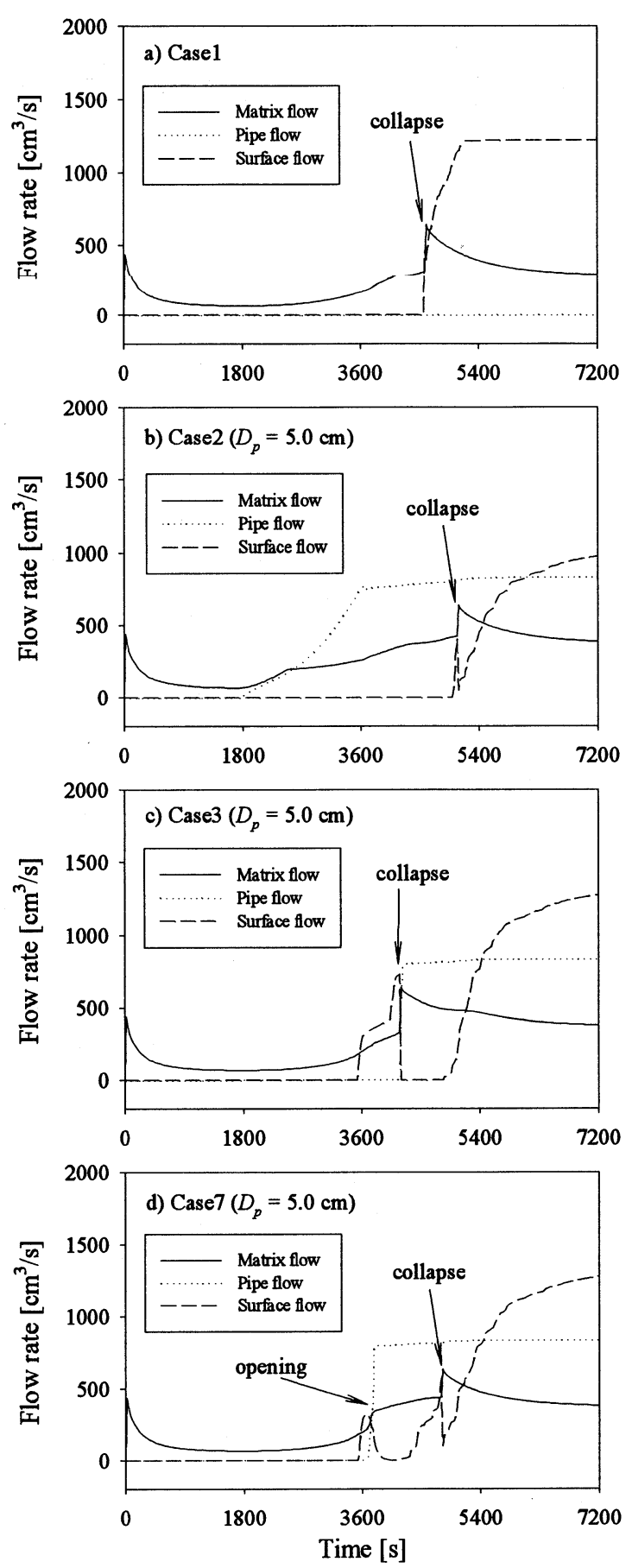

図-5 流出量 (パイプ流，浸透流，表面流）の変化

れを上回る量のパイプ流出が見られ，パイプによる排水 機能が㗢いている事が判る. $t=3500 \mathrm{~s}$ のあたりで, パイ プ流量の増加が止まるが，これはパイプ下流端部のパイ プ流が，開水路流から管路流になった事を表しており， その後はほぼ一定值の排水量を保っている．崩壊直後の 流出量への寄与は, パイプ流によるものが大きいが，そ の後徐々に表面流も増加した。. パイプ下流端部が初めか ら閉塞している場合 (図-5c), 局所的な地下水位の上昇 により早い時期から表面流が発生しているが，すぐには 崩壊していない，崩壊後，パイプの閉塞部がなくなるた め急激にパイプ流による流出が発生している．また，局 所的に地下水位が上昇していた部分が崩壊したため，崩 


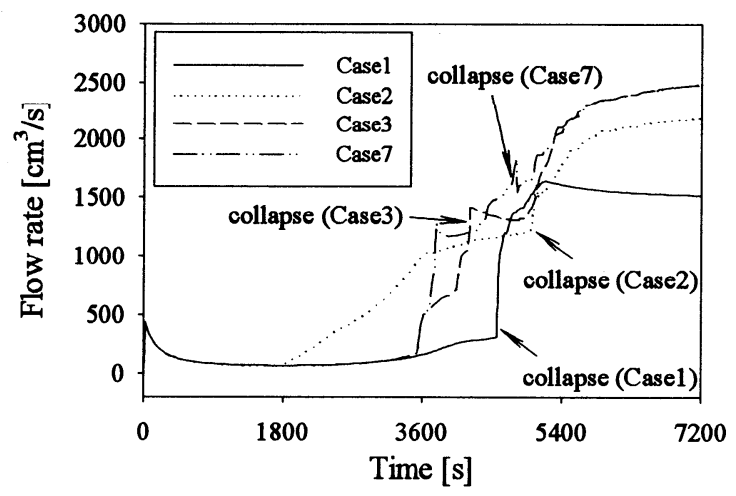

図-6 総流出量の変化 $(d=5.0 \mathrm{~cm})$

壊時に一旦表面流が消失し, その後再び発生している. 崩壊直後の流出量への寄与は, パイプ流によるものが大 きい. 閉塞していたパイプ下流端部が途中で開放される 場合 (図-5d), 閉塞部の開放によりパイプ流による流出 が発生し，それ以前に発生していた表面流が一旦消失す る. その後再ひ表面流が発生し崩壊するが，崩壊後は， 閉塞が無い場合（図-5b）に近い挙動を示す.

総流出量を比較すると（図一6), パイプが無い場合 (Casel)，崩壊前は流出量が少なく土層に保持されてい た水が，崩壊と同時に流出し，急激な流出量の増加をま ねいている. パイプが閉塞しない場合（Case2）, 早い段 階からの流出量増加が見られ, 崩壊後の流出量増加も比 較的緩やかである. パイプ下流端部が初めから閉塞して いる場合 (Case3)，崩壊後に一旦流出量の減少が見られ るが, これは先に示した表面流の消失によるものである. 閉塞していたパイプ下流端部が途中で開放される場合

(Case7), パイプ開放時に流出量の急増を示した後, 複 雑な挙動を示すが, 崩壊時の流出量はここに示した 4Case の中で最も多い.

崩壊後には，崩壊位置の違いによる降雨流入量の差が 生じるため, 単純に比較する事はできないが, ここに示 したように，崩壊前後の流出量の挙動にそれぞれ特徴が あり，崩壊土に供給される水量がパイプの有無やパイプ の閉塞条件によってそれぞれ異なる事が示された.この ため, パイプ流は斜面の安定性に影響するだけでなく， 崩壊後の土塊の流動化にも大きく影響するものと考えら れ，今後さらに検討する必要がある.

\section{4. おわりに}

本研究では，パイプー土㙵間の水移動を適切に評価し たモデルにより，パイプが存在する斜面土壤中の水移動 についての計算手法を構筑した.この手法を用いて最も 単純な斜面・境界条件を想定して斜面安定性に関する数 值実験を行い，以下の事を明らかとした。

(1) 降雨途中でパイプが閉塞し，その部分の間隙水圧が 上昇することで斜面安定性が低下寸る現象が，数値計算 上再現され，ある条件下ではその仮説が正しいことが裏
付けられた.

(2) パイプの閉塞による崩罱け，閉塞部の直上流部で起 こる可能性が高い. また, 排水能力の大きいパイプは, 土層の間隙水圧上昇を抑制し安定化に寄与するが，それ が閉塞している場合は，局所的な間隙水圧上昇が大きく， 逆に危険である.

(3) 崩壊前後の流出量の挙動はパイプの有無やパイプの 閉塞条件によって異なり，崩壊後の土砂の流動化にも異 なる影響を及ぼす事が予想され，更なる検討を必要とす る.

謝辞 : この研究の遂行にあたり, 京都大学農学研究科助 手小杉賢一朗氏，同大学防災研究所助教授釜井俊孝氏， 国土技術政策総合研究所研究官内田太郎氏には，有益な 意見，指導を頂いた.ここに記して，謝意を表す.

\section{参考文献}

1) Sidle R.C., Tuboyama Y., Noguchi S., Hosoda I, Fujieda M and Shimizu T: Stormflow generation in steep forested headwaters: a linked hydrogeomorphic paradigm, Hydrological Processes, Vol. 14, pp. 369-385, 2000.

2) Tsukamoto Y., Ohota T. and Noguchi H. Hydrological and geomorphological studies of debris slides on forested hillslopes in Japan, International Association of Hydrological Sciences Publication, Vol. 137, pp. 89-98, 1982.

3) Pierson T.C.: Soil pipes and slope stability, Quaternary Journal of Engineering Geology, Vol. 16, pp. 1-11, 1983.

4) 水山高久 : 山腹斜面のパイプフローが表層崩壊発生に与え る影響に関する研究，文部省科研費報告書,pp. 1-33, 1994.

5) Nieber J.L. and Wamer GS.: Soil pipe contribution to steady subsurface stormflow, Hydrological Processes, Vol. 5, pp. 329-344, 1991.

6) Jones J.A.A. and Connelly L.J.: A semi-distributed simulation model for natural pipeflow, Journal of Hydrology, Vol. 262, pp. 28-49, 2002.

7) 渡辺邦夫，今井久 : 水みちを持つ斜面内の非定常地下水流 れの性質, 応用地質, Vol. 25, pp. 1-8, 1984.

8) 内田太郎, 水山高久 : パイプ流が斜面の安全率の変化に及 ぼす影響に関する数值計算を用いた考察, 砂防学会誌, Vol. 55, pp. 14-23, 2002.

9）北原曜 : 森林土贌におけるパイプ流の特性, 水文・水資源 学会誌, Vol. 5, No. 1, pp. 15-25, 1992.

10) Sidle R.C., Kitahara H, Terajima T. and Nakai Y.: Experimental studies on the effects of pipeflow on throughflow partitioning, Journal of Hydrology, Vol. 165, pp. 207-219, 1995.

11) Kosugi, K: Lognormal distribution model for unsaturated soil hydraulic properties, Water Resources Research, Vol. 32, pp. 2697-2703, 1996. 